\title{
Synthesis, Acid and Base Resistance of Various Copper Phosphate Pigments by the Substitution with Lanthanum
}

\author{
Hiroaki Onoda ${ }^{1}$, Kenichi Okumoto ${ }^{2}$ \\ ${ }^{1}$ Department of Informatics and Environmental Sciences, Faculty of Life and Environmental Sciences, Kyoto Prefectural University, \\ Kyoto, Japan; ${ }^{2}$ Taihei Chemical Industrial Co., Ltd., Nara, Japan \\ E-mail: onoda@kpu.ac.jp
}

Received November $30^{\text {th }}, 2010$; revised February $16^{\text {th }}, 2011$; accepted February $2^{\text {th }}, 2011$.

\begin{abstract}
Transition metal phosphates are used as inorganic pigments, however these materials have a weak point for acid or base resistance. Because lanthanum phosphate is insoluble in acidic or basic solution, the addition of lanthanum was tried to improve the acid or base resistance of copper phosphate pigment. Various cooper - lanthanum phosphates were synthesized in wet $\left(\mathrm{H}_{3} \mathrm{PO}_{4}, \mathrm{Cu}\left(\mathrm{NO}_{3}\right)_{2}, \mathrm{La}\left(\mathrm{NO}_{3}\right)_{3}\right)$ or dry $\left(\mathrm{H}_{3} \mathrm{PO}_{4}, \mathrm{CuCO} \cdot \mathrm{Cu}(\mathrm{OH})_{2} \cdot \mathrm{H}_{2} \mathrm{O}, \mathrm{La}_{2} \mathrm{O}_{3}\right)$ processes. The additional effects of lanthanum were studied on the chemical composition, particle shape and size distribution, specific surface area, color, acid and base resistance of the precipitates and their thermal products.
\end{abstract}

Keywords: Copper Phosphate, Pigment, Powder Properties, Acid and Base Resistance

\section{Introduction}

Phosphates have been used for ceramic materials, catalysts, fluorescent materials, dielectric substances, metal surface treatment, detergent, food additives, fuel cells, pigments, etc [1-3]. In these applications, transition metal phosphate is suitable as a pigment because of high anticorrosion properties [4-7]. However, there is a weak point that is a certain degree of solubility for acidic and basic solution.

It is well known that rare earth phosphates are insoluble for acidic and basic solution in the groups of phosphate materials. In general, the addition of rare earth elements gives higher functional properties to the material [8]. Consequently, the addition of rare earth cation had the anticipation to improve the acid and base resistance of inorganic phosphate pigments. In previous work, the addition of rare earth cation was studied in solid state syntheses and powder properties, acid and base resistance of cobalt orthophosphate, pyrophosphate, and cyclo-tetraphosphate [3]. The chemical composition and powder properties of thermal products were changed by the addition of rare earth cation. Furthermore, this addition improved the acid and base resistance of phosphate materials synthesized in solid state reaction.

For the syntheses of inorganic phosphates, there are some methods, one is based on the solid state reaction, another one is on the cation exchange reaction in aqueous solution. The method by the solid state reaction had some merits to be easy to form condensed phosphate and to control the molar ratio of cation/phosphorus, on the other hand, had a demerit to be difficult to keep the homogeneity of materials. The preparation of transition metal phosphate in aqueous solution had an advantage to obtain the homogenized materials and various kinds of metal phosphates. However, it had a weak point to be difficult to control the molar ratio of cation/phosphorus. The synthetic method had much influence on the properties of phosphate materials. There are some cases that the phosphate prepared in aqueous solution has the different properties with the phosphate synthesized in solid state reaction. It is important to clear the additional effects of rare earth cation on syntheses of inorganic phosphate materials prepared in wet process and their properties. The addition of rare earth cation causes the change of chemical composition, powder, and functional properties.

The substitution with lanthanum in nickel and cobalt phosphate materials prepared in wet process was studied on the chemical composition, powder condition, color, acid and base resistance $[9,10]$. Specific surface area of 
phosphates increased and particle size became larger by the substitution with lanthanum. The substitution with lanthanum on acid and base resistance was effective for design of inorganic phosphate pigment.

In this work, various copper - lanthanum phosphates were synthesized in aqueous solution or by solid state reaction. The obtained products were evaluated by their particle shape and size distribution, specific surface area, color, acid and base resistance.

\section{Experimental}

\subsection{Synthesis of Various Copper-Lanthanum Phosphates}

The $0.1 \mathrm{~mol} / \mathrm{l}$ of copper nitrate solution was mixed with $0.1 \mathrm{~mol} / \mathrm{l}$ of phosphoric acid solution in the molar ratio of $\mathrm{Cu} / \mathrm{P}=1 / 1$ (wet process). This ratio is settled from the chemical composition of copper orthophosphate, $\mathrm{Cu}-$ $\mathrm{HPO}_{4}$. A part of copper nitrate was substituted with lanthanum nitrate in the molar ratio of $\mathrm{La} / \mathrm{Cu}=0 / 10$ and $2 / 8$. The solutions were mixed in the molar ratio of $\mathrm{P} /(\mathrm{Cu}+$ $\mathrm{La})=1 / 1$. Then, the mixed solution was adjusted to $\mathrm{pH} 7$ by ammonia solution. The precipitate was filtered off and heated at $700^{\circ} \mathrm{C}$ for 1 hour. These preparation ratios are shown in Table 1.

Basic copper carbonate $\left(\mathrm{CuCO}_{3} \cdot \mathrm{Cu}(\mathrm{OH})_{2} \cdot \mathrm{H}_{2} \mathrm{O}\right)$ was mixed with $85 \mathrm{wt} \%$ phosphoric acid $\left(\mathrm{H}_{3} \mathrm{PO}_{4}\right)$ at a mole ratios of $\mathrm{P} / \mathrm{Cu}=2 / 3$ and $1 / 1$ (dry process). Copper orthophosphate, $\mathrm{Cu}_{3}\left(\mathrm{PO}_{4}\right)_{2}$, and pyrophosphate, $\mathrm{Cu}_{2} \mathrm{P}_{2} \mathrm{O}_{7}$, were expected by heating the mixture at $700^{\circ} \mathrm{C}$ for 1 hour via the following reaction.

$$
\begin{gathered}
3 \mathrm{CuCO}_{3} \cdot \mathrm{Cu}(\mathrm{OH})_{2} \cdot \mathrm{H}_{2} \mathrm{O}+4 \mathrm{H}_{3} \mathrm{PO}_{4} \rightarrow \\
2 \mathrm{Cu}_{3}\left(\mathrm{PO}_{4}\right)_{2}+3 \mathrm{CO}_{2}+12 \mathrm{H}_{2} \mathrm{O} \\
\mathrm{CuCO}_{3} \cdot \mathrm{Cu}(\mathrm{OH})_{2} \cdot \mathrm{H}_{2} \mathrm{O}+2 \mathrm{H}_{3} \mathrm{PO}_{4} \rightarrow \\
\mathrm{Cu}_{2} \mathrm{P}_{2} \mathrm{O}_{7}+\mathrm{CO}_{2}+5 \mathrm{H}_{2} \mathrm{O}
\end{gathered}
$$

At the same time, basic copper carbonate was mixed with $85 \mathrm{wt} \%$ phosphoric acid in a mole ratios of $\mathrm{P} / \mathrm{Cu}=$ 2/1. Copper cyclo-tetraphosphate, $\mathrm{Cu}_{2} \mathrm{P}_{4} \mathrm{O}_{12}$, was obtained by heating the mixture at $420^{\circ} \mathrm{C}$ for 1 hour via the following reaction.

$$
\begin{gathered}
\mathrm{CuCO}_{3} \cdot \mathrm{Cu}(\mathrm{OH})_{2} \cdot \mathrm{H}_{2} \mathrm{O}+4 \mathrm{H}_{3} \mathrm{PO}_{4} \rightarrow \\
\mathrm{Cu}_{2} \mathrm{P}_{4} \mathrm{O}_{12}+\mathrm{CO}_{2}+8 \mathrm{H}_{2} \mathrm{O}
\end{gathered}
$$

A part of basic copper carbonate was substituted with lanthanum oxide, $\mathrm{La}_{2} \mathrm{O}_{3}$, in the molar ratio of $\mathrm{La} / \mathrm{Cu}=$ $0 / 10$ and 2/8. These synthetic conditions are also summarized in Table 1.

\subsection{Evaluation of Phosphate Materials}

A part of the precipitates was dissolute in hydrochloric acid solution. The ratios of copper, lanthanum, and phosphorus in the precipitates were calculated from Inductivity Coupled Plasma - Atomic Emission Spectrometry (ICP) results of these solutions. The ICP estimation was measured with Shimadzu ICPS-8000.
The chemical composition of these phosphates was analyzed by X-ray diffraction (XRD) and Fourier transform infrared spectroscopy (FT-IR). X-ray diffraction patterns were recorded on a Rigaku Denki RINT2000M X-Ray diffractometer using monochromated CuKa radiation. The IR spectra were recorded on a Shimadzu FT-IR spectrometer FT-IR8600 with a $\mathrm{KBr}$ disk method.

The powder properties of thermal products were characterized by particle shape, particle size distribution, specific surface area, and their color. Particle shapes were observed by scanning electron micrographs (SEM) using VE8800 from Keyence Co. Ltd. Particle size distribution was measured with laser diffraction/scattering particle size distribution HORIBA LA-910, which can measure samples in the range of 0.02 to $1000 \mu \mathrm{m}$ at one time. Specific surface areas of phosphates were calculated from the amount of nitrogen gas adsorbed at the temperature of liquid nitrogen by BET method with Belsorp mini from BEL JAPAN, INC. The color of phosphate pigments was estimated by ultraviolet-visible (UV-Vis) reflectance spectra with a Shimadzu UV365.

Furthermore, the acid and base resistance of materials was estimated in following method. The $0.1 \mathrm{~g}$ of thermal products was allowed to stand in $100 \mathrm{ml}$ of $0.1 \mathrm{wt} \%$ sulphuric acid or $0.1 \mathrm{wt} \%$ sodium hydroxide solution for 1 day. Then, solid was removed off by filtration. The filtered solution was diluted with nitric acid. The concentrations of phosphorus, copper, lanthanum cation were calculated by ICP results. As a resistance estimation, the solubility (\%) of target elements was calculated for the concentration that thermal products were completely dissolved by warming hydrochloric acid.

\section{Results and Discussion}

\subsection{Chemical Composition of Copper - Lanthanum Phosphates}

Table 1 shows ICP results of samples synthesized in various conditions. The preparation sections were the expected ratios calculated from experimental conditions. Samples prepared in wet process had lower ratio of $\mathrm{P} /(2 \mathrm{Cu}+3 \mathrm{La})$ than the expected ratios (Table 1(a,b)). The obtained precipitates were considered to be phosphorus-poor compounds. Because copper and lanthanum cations were easy to react with phosphoric acid in these ratios, a certain degree of phosphate anion was filtered off [11]. In dry process, the ratio of $\mathrm{P} /(2 \mathrm{Cu}+3 \mathrm{La})$ in precipitates was generally a little lower than those in preparation process (Table 1(c-h)). Small amount of phosphorus was considered to volatilize in heating process. Samples substituted with lanthanum indicated wide range of $\mathrm{La} /(\mathrm{Cu}+\mathrm{La})$ ratio (Table $\mathbf{1}(\mathbf{b}, \mathbf{d}, \mathbf{f}, \mathbf{h}))$, however the average of these ratios was near with the preparation ratio. 
Table 1. ICP results of samples prepared in wet $\left(\mathrm{H}_{3} \mathrm{PO}_{4}+\mathrm{Cu}\left(\mathrm{NO}_{3}\right)_{2}+\mathrm{La}\left(\mathrm{NO}_{3}\right)_{3}\right)$ and dry $\left(\mathrm{H}_{3} \mathrm{PO}_{4}+\mathrm{CuCO} \cdot \mathrm{Cu}(\mathrm{OH})_{2} \cdot \mathrm{H}_{2} \mathrm{O}+\right.$ $\mathrm{La}_{2} \mathrm{O}_{3}$ ) processes.

\begin{tabular}{ccccccc}
\hline & & expected & \multicolumn{2}{c}{ Preparation } & \multicolumn{2}{c}{ Precipitate } \\
\hline & & composition & $\mathrm{P} /(2 \mathrm{Cu}+3 \mathrm{La})$ & $\mathrm{La} /(\mathrm{Cu}+\mathrm{La})$ & $\mathrm{P} /(2 \mathrm{Cu}+3 \mathrm{La})$ & $\mathrm{La} /(\mathrm{Cu}+\mathrm{La})$ \\
$\mathrm{a}$ & wet & $\mathrm{CuHPO}_{4}$ & $1 / 2$ & 0 & 0.263 & 0 \\
b & wet & $\mathrm{CuHPO}_{4}-\mathrm{La}$ & $1 / 2.2$ & $1 / 5$ & 0.261 & 0.149 \\
c & dry & $\mathrm{Cu}_{3}\left(\mathrm{PO}_{4}\right)_{2}$ & $1 / 3$ & 0 & 0.333 & 0 \\
d & dry & $\mathrm{Cu}_{3}\left(\mathrm{PO}_{4}\right)_{2}-\mathrm{La}$ & $1 / 3$ & $1 / 5$ & 0.317 & 0.237 \\
e & dry & $\mathrm{Cu}_{2} \mathrm{P}_{2} \mathrm{O}_{7}$ & $1 / 2$ & 0 & 0.395 & 0 \\
f & dry & $\mathrm{Cu}_{2} \mathrm{P}_{2} \mathrm{O}_{7}-\mathrm{La}$ & $1 / 2$ & $1 / 5$ & 0.522 & 0.232 \\
g & dry & $\mathrm{Cu}_{2} \mathrm{P}_{4} \mathrm{O}_{12}$ & 1 & 0 & 0.960 & 0 \\
h & dry & $\mathrm{Cu}_{2} \mathrm{P}_{4} \mathrm{O}_{12}-\mathrm{La}$ & 1 & $1 / 5$ & 0.845 & 0.188 \\
\hline
\end{tabular}

Figure 1 shows XRD patterns of samples synthesized in various conditions. Samples prepared in wet process indicated the peak patterns of $\mathrm{Cu}_{3}\left(\mathrm{PO}_{4}\right)_{2}$ (JCPDS No. 21-0298) and $\mathrm{Cu}_{4} \mathrm{O}\left(\mathrm{PO}_{4}\right)_{2}$ (JCPDS No.31-0471) (Figure 1(a)). Because sample was the mixture of $\mathrm{Cu}_{3}\left(\mathrm{PO}_{4}\right)_{2}$ and $\mathrm{Cu}_{4} \mathrm{O}\left(\mathrm{PO}_{4}\right)_{2}$, the ratio of $\mathrm{P} /(2 \mathrm{Cu}+3 \mathrm{La})$ became lower (Table 1(a)). By the substitution with lanthanum, these XRD peaks became much weaker (Figure 1 (b)). The lanthanum cations caused the strain and defects in crystalline structure of copper phosphates. Samples synthesized in dry process were copper orthophosphate $\left(\mathrm{Cu}_{3}\right.$ $\left(\mathrm{PO}_{4}\right)_{2}$, JCPDS No.21-0298), pyrophosphate $\left(\mathrm{Cu}_{2} \mathrm{P}_{2} \mathrm{O}_{7}\right.$, JCPDS No. 21-0880), and cyclo-tetraphosphate $\left(\mathrm{Cu}_{2} \mathrm{P}_{4} \mathrm{O}_{12}\right.$, JCPDS No. 29-0572) corresponding with preparationcondition (Figures 1(c,e,g)). By the substitution with lanthanum, XRD peaks of copper phosphates became weak and no peak related with lanthanum compound appeared.

Figure 2 shows IR spectra of samples synthesized in various conditions. Samples with and without lanthanum had similar spectra in IR analyses. The substitution with lanthanum had less influence on phosphate structure in materials. Samples prepared in aqueous solution (Figures 2(a,b)) indicated common absorption peaks with copper orthophosphate synthesized in resemble solid

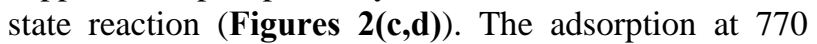
$\mathrm{cm}^{-1}$ was due to the P-O-P bonding in condensed phosphates. Copper cyclo-tetraphosphate (Figures 2(g,h)) had larger peak at $770 \mathrm{~cm}^{-1}$ than copper pyrophosphate (Figures 2(e,f)).

\subsection{Powder Properties of Copper-Lanthanum Phosphates}

Figure 3 shows typical SEM images of samples synthesized in various conditions. All samples had no specified shape. Random shape of phosphate particles covered the surface of stage. Figure 4 shows the particle size distribution of samples synthesized in various conditions.
Copper condensed phosphates, pyrophosphate and cyclo-tetraphosphate, had larger size of particles than copper orthophosphate. By the substitution with lanthanum, the ratio of smaller particles than $100 \mu \mathrm{m}$ increased.

Table 2 shows the specific surface area of samples synthesized in various conditions. Specific surface area has influence on the particle size, color, and solubility of phosphate materials. All samples had smaller specific surface area than $10 \mathrm{~m}^{2} \mathrm{~g}^{-1}$. The substitution with lanthanum improved the specific surface area of phosphate materials. Specific surface area became small with the

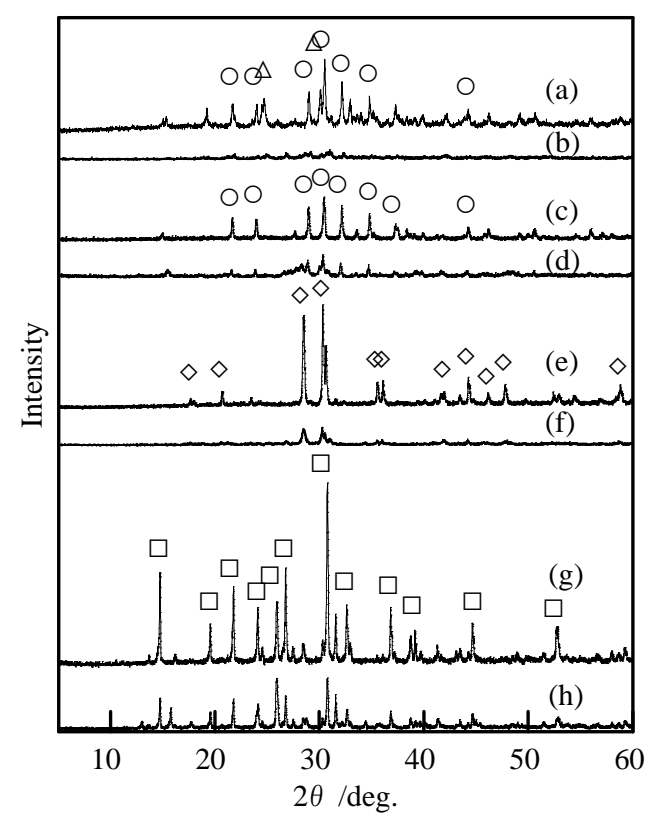

Figure 1. XRD patterns of samples prepared in wet $\left(\mathrm{H}_{3} \mathrm{PO}_{4}\right.$ $\left.+\mathrm{Cu}\left(\mathrm{NO}_{3}\right)_{2}+\mathrm{La}\left(\mathrm{NO}_{3}\right)_{3}\right)$ and dry $\left(\mathrm{H}_{3} \mathrm{PO}_{4}+\mathrm{CuCO}_{3}\right.$. $\left.\mathrm{Cu}(\mathrm{OH})_{2} \cdot \mathrm{H}_{2} \mathrm{O}+\mathrm{La}_{2} \mathrm{O}_{3}\right)$ processes, (a) Wet, $\mathrm{P} /(2 \mathrm{Cu}+3 \mathrm{La})=$ 1/2, La/Cu = 0/10, (b) Wet, 1/2.2, 2/8, (c) Dry, 1/3, 0/10, (d) dry, 1/3, 2/8 (e) Dry, 1/2, 0/10, (f) Dry, 1/2, 2/8, (g) Dry, 1, 0/10, and (h) Dry, 1, 2/8, ○; $\mathrm{Cu}_{3}\left(\mathrm{PO}_{4}\right)_{2}, \triangle ; \mathrm{Cu}_{4} \mathrm{O}\left(\mathrm{PO}_{4}\right)_{2}, \diamond$; $\mathrm{Cu}_{2} \mathbf{P}_{2} \mathrm{O}_{7}, \square ; \mathrm{Cu}_{2} \mathbf{P}_{4} \mathbf{O}_{12}$. 


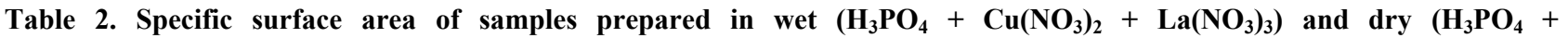
$\left.\mathrm{CuCO}_{3} \cdot \mathrm{Cu}(\mathrm{OH})_{2} \cdot \mathrm{H}_{2} \mathrm{O}+\mathrm{La}_{2} \mathrm{O}_{3}\right)$ processes $/ \mathrm{m}^{2} \cdot \mathrm{g}^{-1}$.

\begin{tabular}{ccccc}
\hline & Preparation ratio $\mathrm{P} /(2 \mathrm{Cu}+3 \mathrm{La})$ & Main composition & Non La & La \\
\hline wet & $1 / 2$ & $\mathrm{Cu}_{3}\left(\mathrm{PO}_{4}\right)_{2}+\mathrm{CuO}$ & 5.82 & 6.25 \\
dry & $1 / 3$ & $\mathrm{Cu}_{3}\left(\mathrm{PO}_{4}\right)_{2}$ & 3.26 & 4.77 \\
dry & $1 / 2$ & $\mathrm{Cu}_{2} \mathrm{P}_{2} \mathrm{O}_{7}$ & 1.25 & 2.66 \\
dry & 1 & $\mathrm{Cu}_{2} \mathrm{P}_{4} \mathrm{O}_{12}$ & 0.03 & 0.31 \\
\hline
\end{tabular}

increasing of condensation degree of phosphate anion.

The color of samples prepared in wet process was the middle of light blue and green. Samples synthesized in dry process were light blue. By the substitution with lanthanum, samples synthesized in wet and dry processes whitened a little. Figure 5 shows UV-Vis reflectance spectra of samples synthesized in various conditions. Samples prepared in wet process had broad reflectance at 520 nm (Figures 5(a,b)). No novel adsorption appeared by the substitution with lanthanum. Samples prepared in dry process indicated the broad reflectance peak from 390 to $600 \mathrm{~nm}$ (Figures 5(c-h)). The structure of phosphate had less influence on color of materials.

\subsection{Acid and Base Resistance Estimation of Phosphates}

Table 3 shows the acid and base resistance of samples synthesized in various conditions. The small number of

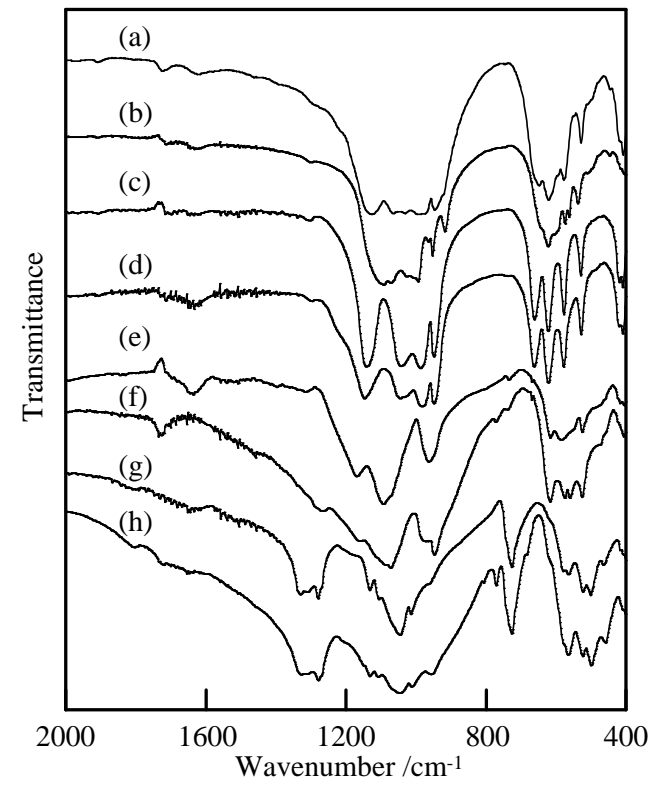

Figure 2. IR spectra of samples prepared in wet $\left(\mathrm{H}_{3} \mathrm{PO}_{4}+\right.$ $\left.\mathrm{Cu}\left(\mathrm{NO}_{3}\right)_{2}+\mathrm{La}\left(\mathrm{NO}_{3}\right)_{3}\right)$ and dry $\left(\mathrm{H}_{3} \mathrm{PO}_{4}+\mathrm{CuCO}_{3}\right.$. $\left.\mathrm{Cu}(\mathrm{OH})_{2} \cdot \mathrm{H}_{2} \mathrm{O}+\mathrm{La}_{2} \mathrm{O}_{3}\right)$ processes, (a) Wet, $\mathrm{P} /(2 \mathrm{Cu}+3 \mathrm{La})=$ 1/2, La/Cu = 0/10, (b) Wet, 1/2.2, 2/8, (c) Dry, 1/3, 0/10, (d) Dry, 1/3, 2/8 (e) Dry, 1/2, 0/10, (f) Dry, 1/2, 2/8, (g) Dry, 1, 0/10, and (h) Dry, 1, 2/8.

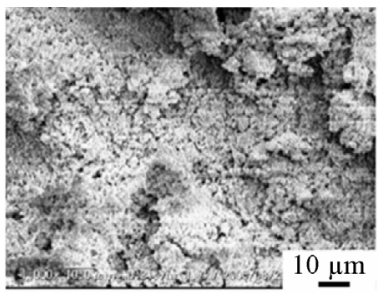

(a)

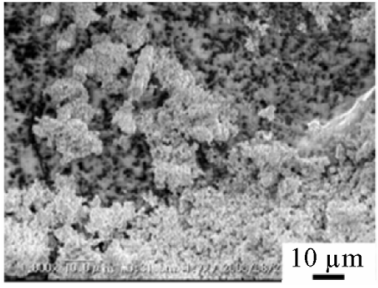

(c)

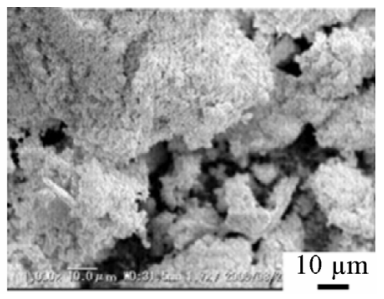

(b)

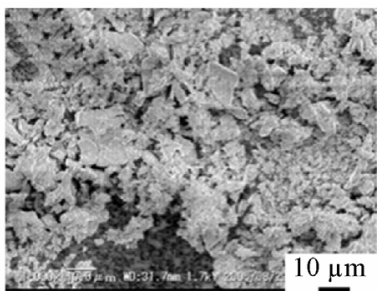

(d)
Figure 3. SEM images of samples prepared in wet $\left(\mathrm{H}_{3} \mathrm{PO}_{4}+\right.$ $\left.\mathrm{Cu}\left(\mathrm{NO}_{3}\right)_{2}+\mathrm{La}\left(\mathrm{NO}_{3}\right)_{3}\right)$ and dry $\left(\mathrm{H}_{3} \mathrm{PO}_{4}+\mathrm{CuCO}_{3} \cdot \mathrm{Cu}(\mathrm{OH})_{2} \cdot \mathrm{H}_{2} \mathrm{O}\right.$ $\left.+\mathrm{La}_{2} \mathrm{O}_{3}\right)$ processes, (a) Wet, $\mathrm{P} /(2 \mathrm{Cu}+3 \mathrm{La})=1 / 2, \mathrm{La} / \mathrm{Cu}=$ 0/10, (b) wet, 1/2.2, 2/8, (c) Dry, P/(2Cu $+3 \mathrm{La})=1 / 3, \mathrm{La} / \mathrm{Cu}$ $=0 / 10$ and $(\mathrm{d})$ Dry, 1/3, $2 / 8$.

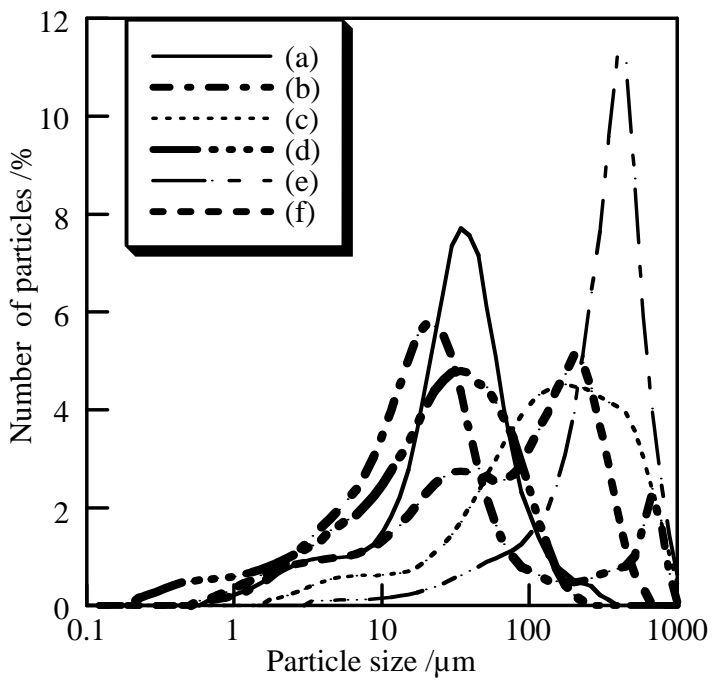

Figure 4. Particle size distribution of samples prepared in dry $\left(\mathrm{H}_{3} \mathrm{PO}_{4}+\mathrm{CuCO}_{3} \cdot \mathrm{Cu}(\mathrm{OH})_{2} \cdot \mathrm{H}_{2} \mathrm{O}+\mathrm{La}_{2} \mathrm{O}_{3}\right)$ process, (a) Dry, $\mathrm{P} /(2 \mathrm{Cu}+3 \mathrm{La})=1 / 3, \mathrm{La} / \mathrm{Cu}=0 / 10$, (b) Dry, 1/3, 2/8, (c) Dry, 1/2, 0/10, (d) Dry, 1/2, 2/8, (e) Dry, 1, 0/10, and (f) Dry, $1,2 / 8$. 
Table 3. Acid and base resistance of samples prepared in wet $\left(\mathrm{H}_{3} \mathrm{PO}_{4}+\mathrm{Cu}\left(\mathrm{NO}_{3}\right)_{2}+\mathrm{La}\left(\mathrm{NO}_{3}\right)_{3}\right)$ and dry $\left(\mathrm{H}_{3} \mathrm{PO} \mathrm{O}_{4}+\mathrm{Cu}-\right.$ $\left.\mathrm{CO}_{3} \cdot \mathrm{Cu}(\mathrm{OH})_{2} \cdot \mathrm{H}_{2} \mathrm{O}+\mathrm{La}_{2} \mathrm{O}_{3}\right)$ processes.

\begin{tabular}{cccccccccc}
\hline & dry/ & \multicolumn{2}{c}{ Preparation ratio } & \multicolumn{3}{c}{ Acid (solubility) } & \multicolumn{3}{c}{ Base (solubility) } \\
& wet & $\mathrm{P} /(2 \mathrm{Cu}+3 \mathrm{La})$ & $\mathrm{La} /(\mathrm{Cu}+\mathrm{La})$ & $\mathrm{P} / \%$ & $\mathrm{Cu} / \%$ & $\mathrm{La} / \%$ & $\mathrm{P} / \%$ & $\mathrm{Cu} / \%$ & $\mathrm{La} / \%$ \\
\hline a & wet & $1 / 2$ & 0 & 100 & 100 & - & 11.7 & 0.6 & - \\
b & wet & $1 / 2.2$ & $1 / 5$ & 100 & 100 & 0.3 & 7.9 & 0 & 0 \\
c & dry & $1 / 3$ & 0 & 100 & 100 & - & 3.7 & 0 & - \\
d & dry & $1 / 3$ & $1 / 5$ & 98.0 & 100 & 34.9 & 6.9 & 0 & 0 \\
e & dry & $1 / 2$ & 0 & 100 & 100 & - & 4.5 & 0.2 & - \\
f & dry & $1 / 2$ & $1 / 5$ & 63.8 & 79.0 & 9.2 & 1.7 & 0 & 0.2 \\
g & dry & 1 & 0 & 32.9 & 33.9 & - & 9.3 & 0 & - \\
h & dry & 1 & $1 / 5$ & 16.3 & 22.2 & 3.5 & 8.1 & 0.9 & 0 \\
\hline
\end{tabular}

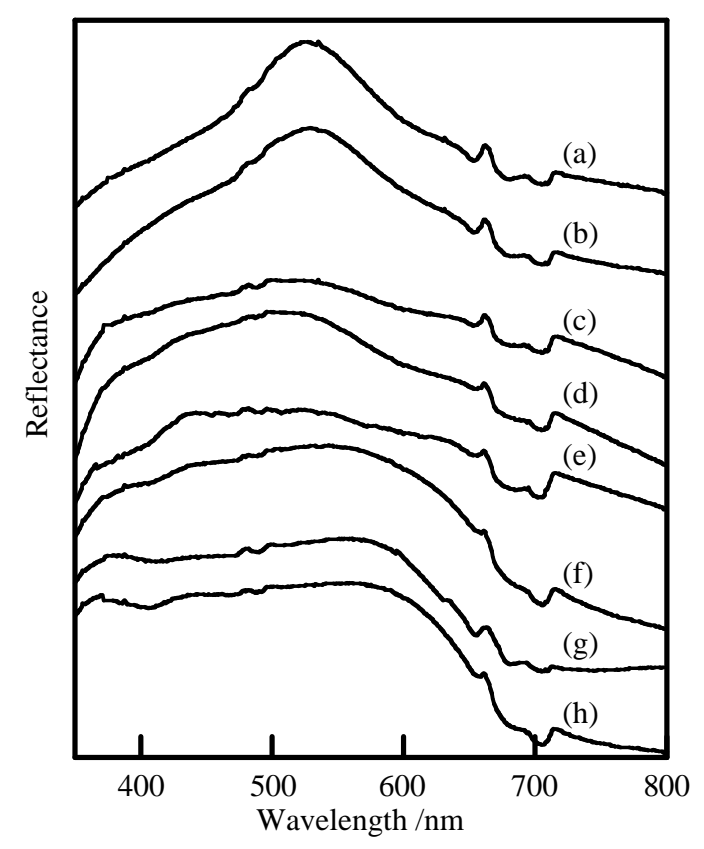

Figure 5. UV-Vis reflectance spectra of samples prepared in wet $\left(\mathrm{H}_{3} \mathrm{PO}_{4}+\mathrm{Cu}\left(\mathrm{NO}_{3}\right)_{2}+\mathrm{La}\left(\mathrm{NO}_{3}\right)_{3}\right)$ and dry $\left(\mathrm{H}_{3} \mathrm{PO}_{4}+\right.$ $\left.\mathrm{CuCO}_{3} \cdot \mathrm{Cu}(\mathrm{OH})_{2} \cdot \mathrm{H}_{2} \mathrm{O}+\mathrm{La}_{2} \mathrm{O}_{3}\right)$ processes, (a) Wet, $\mathrm{P} /(2 \mathrm{Cu}$ $+3 \mathrm{La})=1 / 2, \mathrm{La} / \mathrm{Cu}=0 / 10$, (b) Wet, 1/2.2, 2/8, (c) Dry, 1/3, 0/10, (d) Dry, 1/3, 2/8 (e) dry, 1/2, 0/10, (f) dry, 1/2, 2/8, (g) Dry, 1, 0/10, and (h) Dry, 1, $2 / 8$.

solubility means high acid and base resistance. Samples prepared in wet process with and without lanthanum (Table 3(a,b)) solved perfectly in acid solution. The solubility of samples prepared in dry process became small by the substitution with lanthanum. The solubility of phosphorus became lower than those of copper. In base resistance, some samples indicate higher solubility by the substitution with lanthanum. However, generally, the sub stitution with lanthanum improved the base resistance of copper phosphates.

\section{Conclusions}

The chemical composition of samples prepared in wet process was the mixture of $\mathrm{Cu}_{3}\left(\mathrm{PO}_{4}\right)_{2}$ and $\mathrm{Cu}_{4} \mathrm{O}\left(\mathrm{PO}_{4}\right)_{2}$. On the other hand, in dry process, copper orthophosphate, pyrophosphate, and cyclo-tetraphosphate were obtained corresponding to the synthetic ratio of phosphorus and copper. Specific surface area of phosphate materials became larger by the substitution with lanthanum. The color of samples whitened a little. Acid and base resistance of copper phosphates improved by the substitution with lanthanum.

\section{REFERENCES}

[1] H. Onoda, H. Nariai, A. Moriwaki, H. Maki and I. Motooka, "Formation and Catalytic Characterization of Various Rare Earth Phosphates,” Journal of Materials Chemistry, Vol. 12, No. 6, 2002, pp. 1754-1760. doi:10.1039/b110121h

[2] H. Onoda, T. Ohta, J. Tamaki and K. Kojima, "Decomposition of Trifluoromethane over Nickel Pyrophosphate Catalysts Containing Metal Cation,” Applied Catalysis A; General, Vol. 288, No. 1-2, 2005, pp. 98-103. doi:10.1016/j.apcata.2005.04.028

[3] H. Onoda, K. Yokouchi, K. Kojima, and H. Nariai, “Addition of Rare Earth Cation on Formation and Properties of Various Cobalt Phosphates," Materials Science and Engineering B, Vol. 116, No. 2, 2005, pp. 189-195. doi:10.1016/j.mseb.2004.10.002

[4] D. M. Lenz, M. Delamar and C. A. Ferreira, "Improvement of the Anticorrosion Properties of Polypyrrole by Zinc Phosphate Pigment Incorporation," Progress in Organic Coatings, Vol. 58, No. 1, 2007, pp. 64-69. doi:10.1016/j.porgcoat.2006.12.002

[5] M. Mahdavian and M. M. Attar, "Investigation on Zinc Phosphate Effectiveness at Different Pigment Volume Concentrations via Electrochemical Impedance Spectroscopy," Eletrochimica Acta, Vol. 50, No. 24, 2005, pp. 4645-4648. doi:10.1016/j.electacta.2005.02.015 
[6] M. A. Hernandez, F. Galliano and D. Landolt, "Mechanism of Cathodic Delamination Control of Zinc - Aluminum Phosphate Pigment in Waterborne Coatings,” Corrosion Science, Vol. 46, No. 9, 2004, pp. 2281-2300. doi:10.1016/j.corsci.2004.01.009

[7] M. C. Deya, G. Blustein, R. Romagnoli and B. del Amo, "The Influence of the Anion Type on the Anticorrosive Behaviour of Inorganic Phosphates," Surface and Coating Technology, Vol. 150, No. 2-3, 2002, pp. 133-142. doi:10.1016/S0257-8972(01)01522-5

[8] N. E. Topp, "Chemistry of the Rare Earth Elements," Kagakudojin, Kyoto, 1974.

[9] H. Onoda, H. Matsui and I. Tanaka, "Improvement of Acid and Base Resistance of Nickel Phosphate Pigment by the Addition of Lanthanum Cation," Materials Science and Engineering B, Vol. 141, No. 1-2, 2007, pp. 28-33. doi:10.1016/j.mseb.2007.05.009

[10] H. Onoda, K. Tange and I. Tanaka, "Influence of Lanthanum Addition on Preparation and Powder Properties of Cobalt Phosphates,” Journal of Materials Science, Vol. 43, No. 16, 2008, pp. 5483-5488. doi:10.1007/s10853-008-2831-7

[11] J. Liu, F. Wang, K. Sun and X. Xu, "Creation of a Monomeric Ruthenium Species on the Surface of Micro-Size Copper Hydrogen Phosphate: An Active Heterogeneous Catalyst for Selective Aerobic Oxidation of Alcohols," Advanced Synthesis and Catalysis, Vol. 349, No. 16, 2007, pp. 2439-2444. doi:10.1002/adsc.200700187 